\title{
STUDYING THE CYTOTOXIC AND ANTIOXIDANT ACTIVITIES OF CRUDE EXTRACTS FROM ANACYCLUS NIGELLIFOLIUS BOISS GROWN IN NORTH LEBANON
}

\author{
HUSSEIN FARHAN ${ }^{1,2 *}$ \\ ${ }^{1}$ Department of Biotechnology, University of Baghdad Science College, Baghdad, Iraq. ${ }^{2}$ Research Platform for Environmental Science \\ (PRASE)/Doctoral School of Science and Technology, Lebanese University, Lebanon. Email: husseinfarhan1978@yahoo.com
}

Received: 01 July 2017, Revised and Accepted: 30 October 2017

\section{ABSTRACT}

Objective: The objective of this study is to evaluate the chemical contents (total phenolic and total flavonoid contents) of the crude ethanolic and aqueous extracts from leaves and stems of a Lebanese plant and to evaluate their cytotoxic and antioxidant activities.

Methods: Quantification of the total phenolic and total flavonoid contents of all extracts of Anacyclus nigellifolius from leaves and stems and the cytotoxic activity were evaluated through XTT assay, while antioxidant activities were evaluated using spectrophotometric analyses DPPH, $\mathrm{H}_{2} \mathrm{O}_{2}$, and chelating of ferrous ions tests.

Results: The ethanolic extract from leaves and stem of $A$. nigellifolius was better than aqueous extract and showed a higher content in total phenolic and total flavonoid which was $39.48 \pm 0.04$ and $13 \pm 0.03$, respectively. On the other hand, the best value of IC50 of DPPH, $\mathrm{H}_{2} \mathrm{O}_{2}$, and chelating of ferrous ions of ethanol extract from leaves was $0.1 \mathrm{mg} / \mathrm{mL}, 0.25 \mathrm{mg} / \mathrm{mL}$, and $0.37 \mathrm{mg} / \mathrm{mL}$, respectively, also, ethanol extract has significantly inhibited cells growth $293 \mathrm{~T}$ and MCF7, a percentage of inhibition was in leaves, and it has reached the $70 \%$ and $54 \%$, respectively.

Conclusions: Both ethanolic and aqueous extracts of both parts of $A$. nigellifolius have shown high efficiency and good antioxidant and antiproliferation power. Hence, this plant can be used in the prevention of a number of diseases related to oxidative stress as well as might be used for inhibition of cancer cell line growth.

Keywords: Total phenolic, Total flavonoid, Antioxidant, Cytotoxic potentially.

(C) 2018 The Authors. Published by Innovare Academic Sciences Pvt Ltd. This is an open access article under the CC BY license (http://creativecommons. org/licenses/by/4. 0/) DOI: http://dx.doi.org/10.22159/ajpcr.2018.v11i1.21690

\section{INTRODUCTION}

Oxidative stress is involved in a lot of an acute and chronic disease including cancer, neurodegenerative, and cardiovascular diseases. The balance between antioxidation and oxidation is believed to be critical in maintaining a healthy biological system [1,2]. The wild diversity in nature gives us a variety of useful sources of remedies to cure a number of diseases. Therefore, natural products have played a major role in drug discovery and development, especially agents active against cancer and infectious diseases [3].

Anacyclus nigellifolius Boiss. is an endemic plant to Lebanon their Arabic name: مسطينق and English name: Nigella-leaved anacylus. It is perennial, procumbent herb, found in various region in Lebanon, especially in Arz tannourine, their Botanical descriptions scattered flat hairy plant 20-40 cm; divided, oblong, ovate leaves; white ligules are shorter than disk; outer achenes with large aricles and it belong to Asteraceae or Compositae family [4].

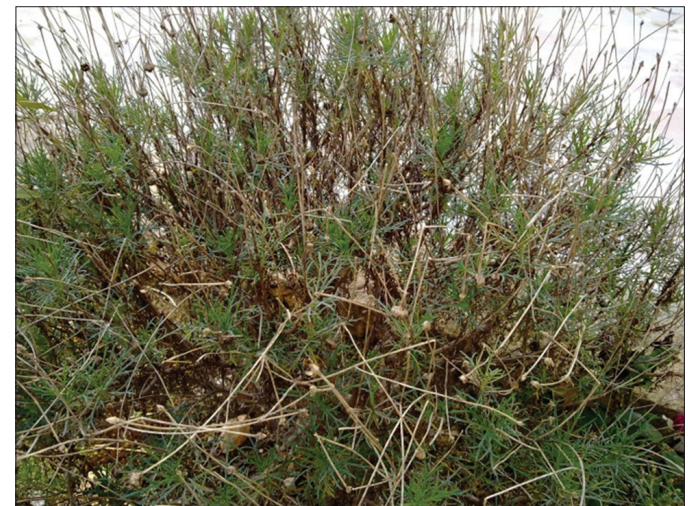

Anacyclus pyrethrum is considered a famous herb in Anacyclus genus many of article have been found their root that owned several activities in folk medicine in different countries is used in the treatment of various neuralgic and rheumatic affection of the head, face and the tooth in Algeria. It is used as a stimulant and tonic to the nervous system, and also, used in respiratory disease. The local ethnobotanical study carried out showed its possible antidiabetic activity $[5,6]$. Furthermore, a recent study shown that A. pyrethrum methanolic and aqueous extracts have a strong antibacterial activity against a wide range of bacteria species [7].

\section{METHODS}

The plant classification of $A$. nigellifolius Boiss. has been done by Professor George Tohme, president of C.N.R.S of Lebanon, this plant is considering as endemic in Lebanon, and it has been collected from west of Lebanon in 2011

\section{Preparation of crude extracts}

$10 \mathrm{~g}$ of milled stems and leaves of $A$. nigellifolius have been soaked by put inside a flask with half of liter of ethanol, afterward the blend being extracted by mixing for $5 \mathrm{~h}$ at $25^{\circ} \mathrm{C}$. Then, the extracts have been left during overnight for $24 \mathrm{~h}$, and later, the ethanolic part was taken by used the syringe. The extraction of residue part has been done through using $150 \mathrm{~mL}$ of ethanol, and the entirely extracts were filtered using filter paper sized 0.45 Millipore. Next step, the both parts of extracts were mixed together and then concentrated using a rotary evaporator at $40^{\circ} \mathrm{C}$ under reduced pressure, and finally, the extracts has been stored at $-20^{\circ} \mathrm{C}$ until they are used in various trails, the extracts, and then are resolved in ethanol and distilled water.

The aqueous extract has been prepared using the same steps of the ethanolic extraction except for the temperature of the extraction should be $60^{\circ} \mathrm{C}[8]$. 
Quantifications of chemical contents

\section{Total phenolic content (TPC)}

The Folin-Ciocalteau reagent method has been used for the estimation of total phenolic extracts quantities according to the study of Lister and Wilson [9] with slight modification. Five concentrations of all extracts of the used plants have been prepared, and then, $100 \mu \mathrm{l}$ have been taken from each concentration and mixed with $0.5 \mathrm{~mL}$ of Folin-Ciocalteau reagent (1/10 dilution) and $1.5 \mathrm{~mL}$ of $\mathrm{Na}_{2} \mathrm{CO}_{3} 2 \%(\mathrm{w} / \mathrm{v})$, the mix kept in dark room for around quarter hour, and all blue-colored solution of samples absorbance has been measured at $765 \mathrm{~nm}$. The results expressed in mg of gallic acid equivalent gram of dry weight of plant.

\section{Total flavonoids content (TFC)}

The approach was used according to the study of Quettier-Deleu et al. [10]. $1 \mathrm{~mL}$ of several concentrations of all crude extracts has been mixed with $1 \mathrm{~mL}$ of $2 \%$ methanolic aluminum chloride solution. Thereafter, left an incubation time around $15 \mathrm{~min}$ at dark room, and subsequently, absorbance of all samples has been taken at $430 \mathrm{~nm}$. Methanol was used as blank, and the results were expressed in mg of rutin equivalent gram of dry weight of plant.

\section{Evaluation of the antioxidant and cytotoxic activities DPPH radical scavenging activity}

The method of Chew et al. [11] has been used for the scavenging ability of DPPH antioxidant test with slight modification, this approach has been done through preparation of $1 \mathrm{~mL}$ of various concentrations of diluted extracts and added to $1 \mathrm{~mL}$ of DPPH, and also, $1 \mathrm{~mL}$ of DPPH with $1 \mathrm{~mL}$ of ethanol has been prepared as a control. All solutions were mixed by hand afterward left in the dark for half hour, and finally, the absorbance was taken at $517 \mathrm{~nm}$. Ascorbic acid has been used as a positive control while ethanol used as a blank. DPPH scavenging ability of plant extracts was calculated using the following equation

$\%$ Scavenging activity $=[($ Abs control - Abs sample $)] /($ Abs control $)]$ $\times 100$

The Abs control is the absorbance of DPPH + ethanol; Abs sample is the absorbance of DPPH radical + sample. Furthermore, three controls have been prepared.

\section{Scavenging activity of hydrogen peroxide $\left(\mathrm{H}_{2} \mathrm{O}_{2}\right)$ radical}

The $\mathrm{H}_{2} \mathrm{O}_{2}$ scavenging of the extracts of leaves and stems of the different plants was determined according to the method of Ruch et al. [12]. A solution of $\mathrm{H}_{2} \mathrm{O}_{2}(40 \mathrm{mM})$ was prepared in PBS (pH 7.4), and concentration was determined spectrophotometrically (Gene Quant 1300 ultraviolet (UV)-visible) at $230 \mathrm{~nm}$. Different concentrations of extracts from stems and leaves of these plants in distilled water were added to a $\mathrm{H}_{2} \mathrm{O}_{2}$ solution $(0.6 \mathrm{~mL}, 40 \mathrm{mM})$, and the absorbance of $\mathrm{H}_{2} \mathrm{O}_{2}$ at $230 \mathrm{~nm}$ was determined after $10 \mathrm{~min}$, a blank solution containing phosphate buffer without $\mathrm{H}_{2} \mathrm{O}_{2}$. Ascorbic acid was used as standard reference.

The percentage scavenging of $\mathrm{H}_{2} \mathrm{O}_{2}$ was calculated using the following equation:

$\%$ Scavenged $\left[\mathrm{H}_{2} \mathrm{O}_{2}\right]=[($ Abs control - Abs sample $) /$ Abs control $] \times 100$

\section{Chelating effects on ferrous ions}

This method has been used to estimate the chelating effect on ferrous ions with some modifications [13]. $0.5 \mathrm{~mL}$ of various concentrations of all extracts was mixed with $0.5 \mathrm{~mL}$ of $\mathrm{FeSO}_{4}(0.12 \mathrm{mM})$ and with $0.5 \mathrm{~mL}$ of ferrozine $(0.6 \mathrm{mM})$. The mixtures were allowed to stand for $10 \mathrm{~min}$ at room temperature. After incubation, the absorbance was measured by Gene Quant 1300 UV-visible spectrophotometrically at $562 \mathrm{~nm}$. Ultrapure water of sample solution was used as a control without extracts, and ultrapure water was used as a blank. EDTA-Na was used as reference standard. All measurements were performed in triplicate. The ferrozine solution (3-[2-Pyridyl]-5,6-diphenyl- 1,2,4-triazine-4,4'-disulfonic acid Na-salt) $(0.6 \mathrm{mM})$ was prepared in ultrapure water and stored in the dark at room temperature. The ability of the sample to chelate ferrous ion was calculated relative to the control (consisting of iron and Ferrozine only), and we were using the formula:

Ferrous ion - chelating ability $(\%)=[($ Abs control - Abs sample $) /$ Abs control] $\times 100$

\section{Cell culture preparation}

MCF7 and 293T semi-adherent were cultured in DME. Medium DMEM was supplemented with $10 \%(\mathrm{v} / \mathrm{v})$ fetal bovine serum and $2 \%$ penicillin-streptomycin solution. The cells were cultured at $37^{\circ} \mathrm{C}$ in a humidified atmosphere containing $5 \% \mathrm{CO}_{2}$. The cell numbers were counted by a hematocytometer, and the viability was always $>95 \%$ in all experiments as assayed by the $0.4 \%$ trypan blue exclusion method. To ensure an exponential growth, cells were resuspended in fresh medium $24 \mathrm{~h}$ before each treatment. Furthermore, we used cell line MCF 10 as normal control, this cell line is cultured in DMEM F12 Ham supplemented with $10 \%(\mathrm{v} / \mathrm{v})$ fetal bovine serum and $2 \%$ penicillinstreptomycin solution, and in addition, the medium requires $50 \mu \mathrm{l}$ hydrocortisone, $25 \mu \mathrm{l}$ insulin, and $5 \mu \mathrm{l}$ cholera toxin.

\section{XTT assay}

The cytotoxicity of the six extracts was tested by the method of XTTformazan dye formation by the method Weislow et al. [14] at various concentrations and with some modifications. Cultured MCF7, 293T, and MCF10 cells were seeded (25,000 cells/well) in a 96-well plate, and then, cells in each well were treated along with different extract dosages $(0.1,0.3,0.5 .0 .7$, and $1 \mathrm{mg} / \mathrm{mL})$. MCF7, 293T, and MCF10 cells were used alone without extracts treatment as a control. After treatment, the 96well plate was incubated for $24 \mathrm{~h}$ maintaining the same conditions. After the incubation period, $25 \mu \mathrm{l}$ of XTT reagent $(0.6 \mathrm{mg} / \mathrm{mL})$ containing $25 \mu \mathrm{M}$ PMS has been added. The plate was further incubated for $2 \mathrm{~h}$ at the same conditions. Absorbance was measured at $490 \mathrm{~nm}$ with reference filter using in an ELX800 Microplate Reader. The percentage of cytotoxicity was calculated by the following formula:

$\%$ Cytotoxicity $=[($ Abs C- Abs T) $/$ Abs C $] \times 100$

Where Abs C is the mean absorbance of the control wells and Abs T is the mean absorbance of tested wells with a particular extract dosage.

Statistical analysis

All analyses were carried out in triplicates. The result of scavenger activity, total phenolic compound, and total flavonoid compound was performed from the averages of all samples reading mean \pm SD used Excel 2003 and other analytical methods. Furthermore, the results of anticancer and antioxidants have been done by SPSS version 16 using Student's t-test $(\mathrm{p}<0.05)$.

\section{RESULTS AND DISCUSSION}

Total phenolic and flavonoids content of A. nigllifolius have been estimated as shown in Table 1. All extracts of both leaves and stems contain high amounts of TPC and TFC.

Values are the average of triplicate experiments and values are expressed as $\mathrm{mg} \pm \mathrm{SD}$

Table 1: Total phenolic and flavonoids content of A. nigllifolius

\begin{tabular}{lllll}
\hline \multirow{2}{*}{$\begin{array}{l}\text { Estimation } \\
\text { Test }\end{array}$} & Leaves & \multicolumn{3}{l}{ Stems } \\
\cline { 2 - 5 } & EtOH & Aqueous & Aqueous & EtOH \\
\hline TPC & $39.48 \pm 0.04$ & $36.9 \pm 0.045$ & $27.6 \pm 0.05$ & $33.52 \pm 0.042$ \\
TFC & $13 \pm 0.03$ & $12.35 \pm 0.057$ & $7.1 \pm 0.05$ & $8.9 \pm 0.054$ \\
\hline
\end{tabular}

TPC: Total phenolic content, TFC: Total flavonoids content,

A. nigllifolius: Anacyclus nigllifolius, GAE: Gallic acid equivalent 
The obtained results showed that the contents in leaves were higher than in stems for both extracts and can be confirmed the result was estimated by the method Hijazi et al. [15] showed that the TPC and TFC of the ethanolic extract of A. nigellifolius were $86.7 \mathrm{mg} / \mathrm{mL}$ TPC and $50.2 \mu \mathrm{g} / \mathrm{mL}$ of TFC, respectively, as well as, the result was estimated by Sujith et al. [16] showed that the TPC and TFC of EtOH extracts of A. pyrethrum were $159.63 \mathrm{mg} / \mathrm{g}$ of TPC and $29.65 \mathrm{mg} / \mathrm{g}$ of TFC. Those results showed that the Anacyclus may have high contents of phenol and flavonoid contents in their parts.

\section{Antioxidant activity}

The obtained results showed that both EtOH and aqueous extracts from leaves of this plant have exerted high antioxidant activity through the three used in vitro assays. This activity was more than $80 \%$ for the DPPH and more than $70 \%$ for the $\mathrm{H}_{2} \mathrm{O}_{2}$ and iron chelating tests as shown in Figs. 1-3.

Figs. 4-6 showed that both EtOH and aqueous extracts from stems of the studied plant have exerted high antioxidant activity through the three used tests. This activity was higher for the EtOH extracts for DPPH and $\mathrm{H}_{2} \mathrm{O}_{2}$ than in aqueous once for iron chelating, and it has reached around $70 \%$ for the three tests of EtOH extracts.

The $\mathrm{IC}_{50}$ for each extract from both leaves and stems of $A$. nigllifolius was evaluated. Our results demonstrated that the $\mathrm{IC}_{50}$ of DPPH, $\mathrm{H}_{2} \mathrm{O}_{2}$,

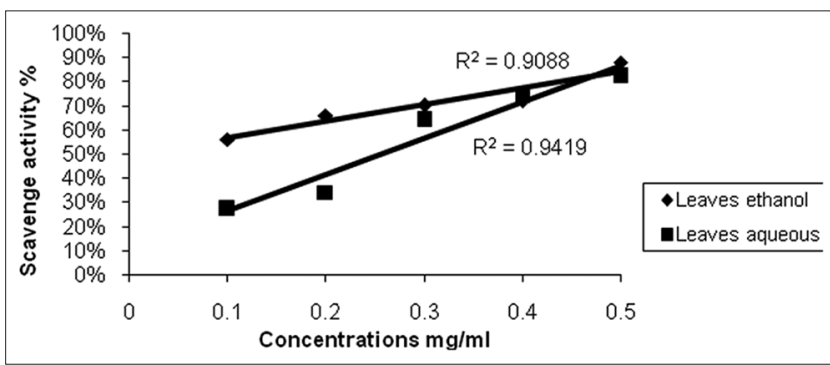

Fig. 1: The scavenging ability of EtOH and aqueous extracts of leaves on DPPH

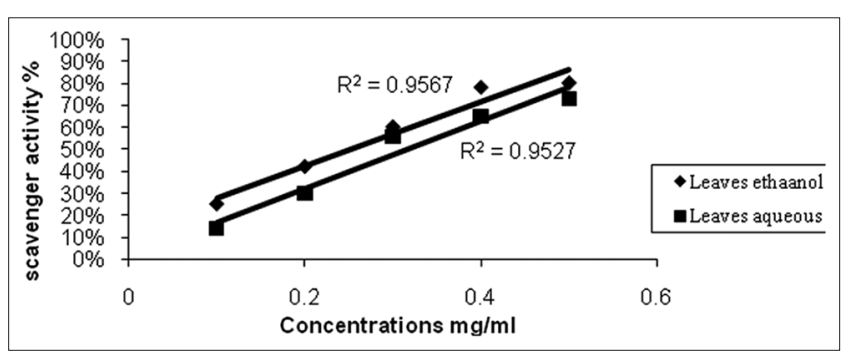

Fig. 2: The scavenging ability of EtOH and aqueous extract of leaves on $\mathrm{H}_{2} \mathrm{O}_{2}$

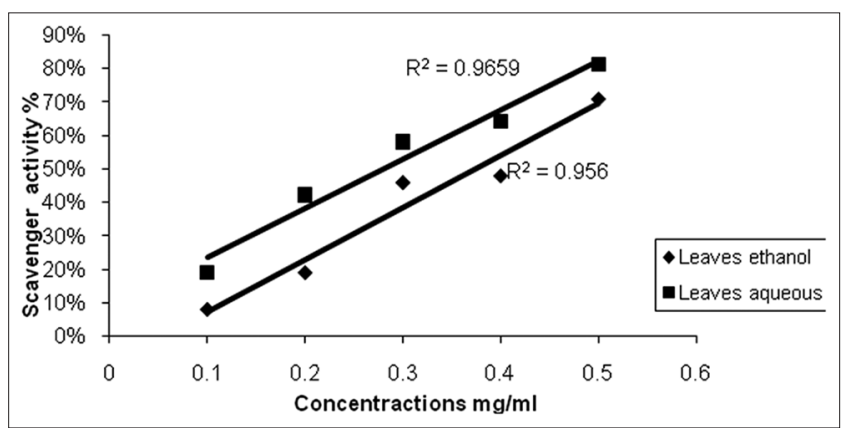

Fig. 3: The scavenging ability of EtOH and aqueous extract of leaves on iron chelating and iron chelating was different between leaves and stems and between extracts from the two parts as shown in Table 2.

This study showed the best value of IC50 of DPPH, $\mathrm{H}_{2} \mathrm{O}_{2}$, and chelating of ferrous ions of ethanol extract from leaves was $0.1 \mathrm{mg} / \mathrm{mL}$, $0.25 \mathrm{mg} / \mathrm{mL}$, and $0.37 \mathrm{mg} / \mathrm{mL}$, respectively, that confirm the ethanolic extract result done by Hijazi et al. [15] which have been demonstrated that DPPH test presented a strong scavenging activity with an IC50 was $0.178 \mathrm{mg} / \mathrm{mL}$

There is closely correlation between the amounts of TPC and TFC and the scavenger activity of extracts. When the quantities of phenol are higher, the antioxidant activity of extracts is higher. The previous studies found that there was a direct relationship between antioxidant activity and TPC in selected herbs, vegetables, and fruits. Phenolic compounds had a major contribution to antioxidant activity [17-19], and there are several studies have been indicated that flavonoids and polyphenols possess antioxidant and free radical scavenging activity from various plants has been grown in Lebanon [20-22].

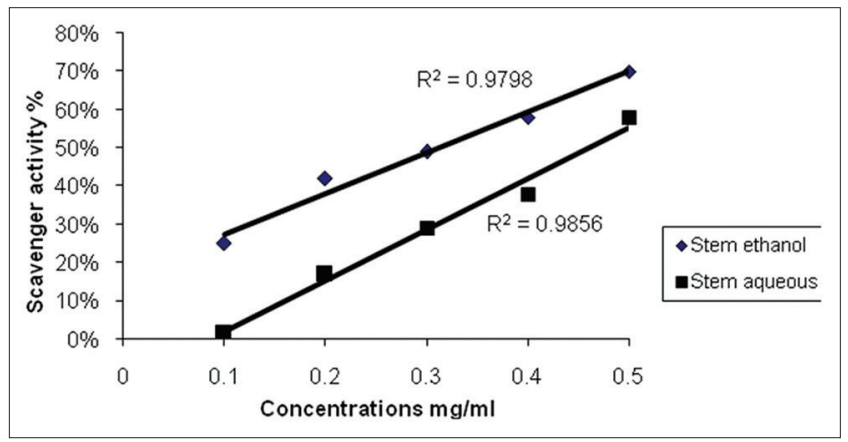

Fig. 4: The scavenging ability of EtOH and aqueous extracts of stem on DPPH

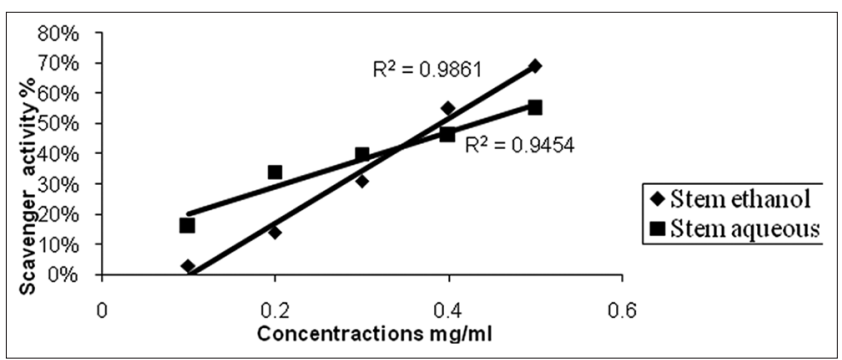

Fig. 5: The scavenging ability of EtOH and aqueous extracts of stems on $\mathrm{H}_{2} \mathrm{O}_{2}$

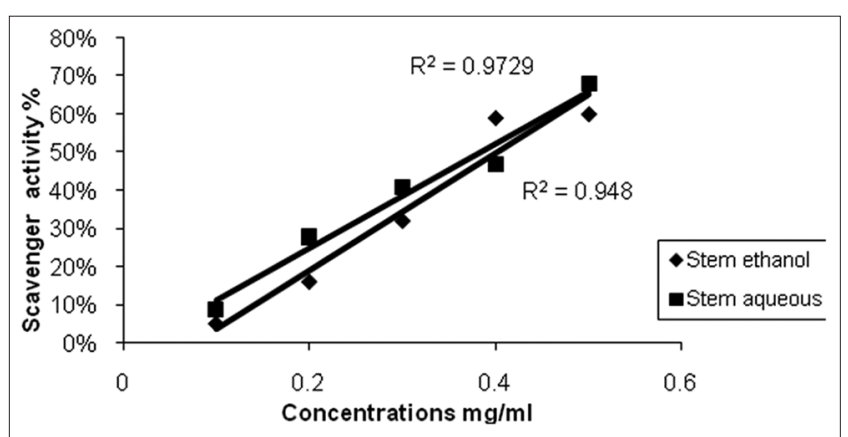

Fig. 6: The scavenging ability of EtOH and aqueous extract of stems on iron chelating 
Table 2: $\mathrm{IC}_{50}$ values of stems and leaves extracts on DPPH, $\mathrm{H}_{2} \mathbf{O}_{2^{\prime}}$ and iron chelating tests

\begin{tabular}{llll}
\hline \multirow{2}{*}{ Extracts } & \multicolumn{1}{l}{ IC $_{50}$} & \\
\cline { 2 - 4 } & DPPH & $\mathbf{H}_{\mathbf{2}} \mathbf{O}_{\mathbf{2}}$ & Fe \\
\hline Ascorbic acid & $2.5 \mu \mathrm{g} / \mathrm{mL}$ & $10 \mu \mathrm{g} / \mathrm{mL}$ & - \\
EDTA & - & - & $5 \mu \mathrm{g} / \mathrm{mL}$ \\
Leaves & & & \\
$\quad$ Aqueous & $0.25 \mathrm{mg} / \mathrm{mL}$ & $0.3 \mathrm{mg} / \mathrm{mL}$ & $0.28 \mathrm{mg} / \mathrm{mL}$ \\
$\quad$ EtOH & $0.1 \mathrm{mg} / \mathrm{mL}$ & $0.25 \mathrm{mg} / \mathrm{mL}$ & $0.37 \mathrm{mg} / \mathrm{mL}$ \\
Stems & & & \\
$\quad$ Aqueous & $0.45 \mathrm{mg} / \mathrm{mL}$ & $0.43 \mathrm{mg} / \mathrm{mL}$ & $0.41 \mathrm{mg} / \mathrm{mL}$ \\
$\quad$ EtOH & $0.31 \mathrm{mg} / \mathrm{mL}$ & $0.39 \mathrm{mg} / \mathrm{mL}$ & $0.38 \mathrm{mg} / \mathrm{mL}$ \\
\hline
\end{tabular}

Values are the average of triplicate experiments, and values are expressed as $\mathrm{mg} \pm \mathrm{SD}$

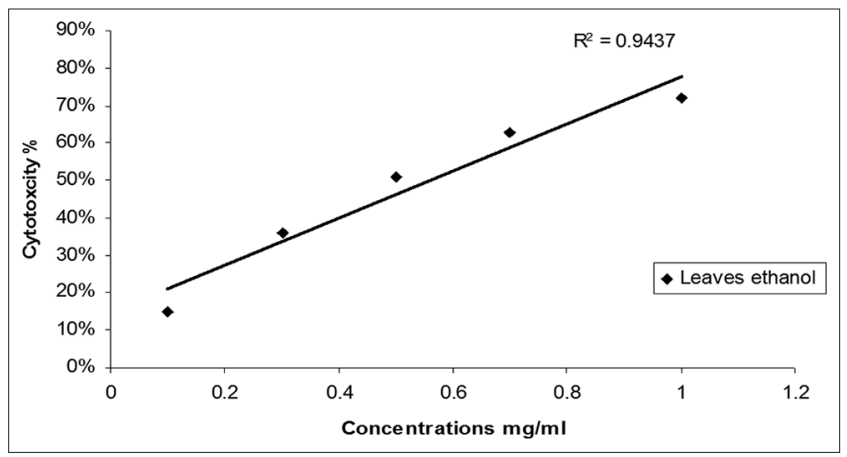

Fig. 7: Inhibition of 293T cell proliferation by the treatments of different concentrations of EtOH extracts from leaves of Anacyclus nigllifolius

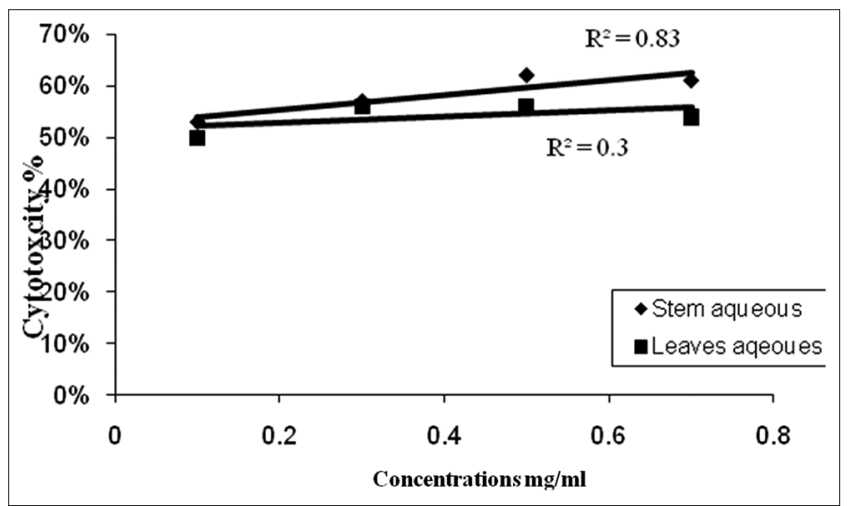

Fig. 8: Inhibition of 293T cell proliferation by the treatments of different concentrations of aqueous extracts from leaves and stems of Anacyclus nigllifolius

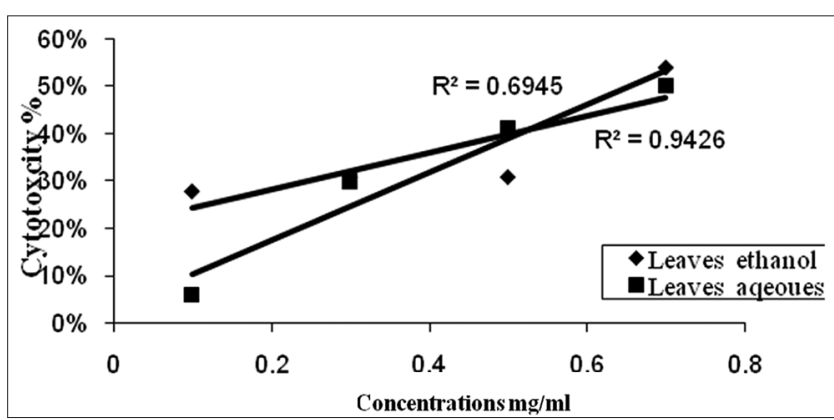

Fig. 9: Inhibition of MCF7 cell proliferation by the treatments of different concentrations of aqueous and EtOH extracts from leaves of Anacyclus nigllifolius

\section{Cancer cell proliferation}

The cytotoxicity of each part of A. nigllifolius on MCF7and 293T cells was examined by XTT assay. After $2 \mathrm{~h}$ of treatment by different concentrations of leaves and stems, it was shown that EtOH extracts have significantly inhibited cell growth 293T. The percentage of inhibition was in leaves, and it has reached the $70 \%$ as shown in Fig. 7. In addition, aqueous extracts of leaves and stems were found their ability to reduce and inhibit the cell lines around $54 \%$ and $61 \%$, respectively, as shown in Fig. 8. Therefore, the aqueous and EtOH extracts from leaves have the ability to inhibit $54 \%$ of MCF7 as shown in Fig. 9. In the same purpose [23], tested hot water polysaccharide extracts of A. pyrethrum for their immunostimulating activity in vitro and in vivo, and they showed a markedly enhancing of the proliferation of the murine spleen cells in vitro. The results of the in vivo study at a dose of $50 \mathrm{mg} / \mathrm{kg}$ also showed that $A$. pyrethrum has better effects than obtained with the in vitro study at $50 \mu \mathrm{g} / \mathrm{mL}$. Another research has been done by Krishnaraju et al. [24] who tested the toxicity of several medicinal plants on brine shrimp lethality bioassay which based on the ability to kill laboratory cultured brine shrimp. Our current study outcome has been proved a previous results that shown the effect of ethanolic extracts of leaves and stems of A. nigellifolius on human lung A549 adenocarcinoma cells.

\section{CONCLUSION}

Briefly, the obtained results demonstrated that the leaves and stems of extracts have a good amount of phenolics and flavonoids. The aqueous and ethanolic extracts showed potent radical-scavenging activities in $\mathrm{DPPH}, \mathrm{H}_{2} \mathrm{O}_{2}$, and iron chelating, and likewise, it have antiproliferative activities in MCF7 and 293T cells. That can be lead us for an important potential role of A. nigllifolius extracts and their efficiency as antioxidant and anticancer from natural origin.

\section{ACKNOWLEDGMENTS}

The author would like to thank the Lebanese University Doctoral School of Science and Technology, Research Platform for Environmental Science (PRASE) for their support of this study and also to thank the Dean of Faculty of science Prof Bassam Badran, Prof Hassan Rammal, and Prof Akram Hijazi.

\section{REFERENCES}

1. Hong H, Liu GQ. Protection against hydrogen peroxide-induced cytotoxicity in PC12 cells by scutellarin. Life Sci 2004;74:2959-73.

2. Farhan H, Malli F, Rammal H, Hijazi A, Bassal A, Ajouz N, et al. Phytochemical screening and antioxidant activity of Lebanese Eryngium creticum L. Asian Pac J Trop Biomed 2012;2(3):1217-20.

3. Butler MS. Natural products to drugs: Natural product-derived compounds in clinical trials. Nat Prod Rep 2008;25:475-516.

4. Tohme G, Tohme H. Illustrated Flora of Lebanon. Beirut Lebanon: National Council for Scientific Research; 2007.

5. Allali H, Benmehdi H, Dib MA, Tabti B, Ghalem S, Benabadji N. Phytotherapy of diabetes in West Algeria. Asian J Chem 2008:20:2701-10.

6. Bellakhdar J. La Pharmacopée Marocaine Traditionnelle: Médecine Arabe Ancienne et Savoirs Populaires - Saint-Etienne, Edit. Paris: Ibis Press; 1997. p. 177.

7. Doudach L, Meddah B, Alnamer R, Chibani F, Cherrah Y. In vitro antibacterial activity of the methanolic and aqueous extracts of Anacyclus pyrethrum used in Moroccan traditional medicine. Int $\mathrm{J}$ Pharm Pharm Sci 2012;4:402-5.

8. Harborne JB. Phytochemical Methods. London: Chapman and Hall, Ltd.; 1973. p. 49-188.

9. Lister E, Wilson P. Measurement of Total Phenolics and ABTS Assay for Antioxidant Activity. New Zealand: Crop Research Institute Lincoln; 2001

10. Quettier-Deleu C, Gressier B, Vasseur J, Dine T, Brunet C, Luyckx M, et al. Phenolic compounds and antioxidant activities of buckwheat (Fagopyrum esculentum moench) hulls and flour. J Ethnopharmacol 2000;72:35-42.

11. Chew YL, Goh JK, Lim YY. Assessment of in vitro antioxidant capacity and polyphenolic composition of selected medicinal herbs 
from leguminosae family in Peninsular Malaysia. Food Chem 2009;116:13-8.

12. Ruch RJ, Cheng SJ, Klaunig JE. Prevention of cytotoxicity and inhibition of intercellular communication by antioxidant catechins isolated from Chinese green tea. Carcinogenesis 1989;10:1003-8.

13. Dinis TC, Maderia VM, Almeida LM. Action of phenolic derivatives (acetaminophen, salicylate, and 5-aminosalicylate) as inhibitors of membrane lipid peroxidation and as peroxyl radical scavengers. Arch Biochem Biophys 1994;315:161-9.

14. Weislow OS, Kiser R, Fine DL, Bader J, Shoemaker RH, Boyd MR, et al. New soluble-formazan assay for HIV-1 cytopathic effects: Application to high-flux screening of synthetic and natural products for AIDS-antiviral activity. J Natl Cancer Inst 1989;81:577-86.

15. Hijazi A, Sabbah A, Falah AS, Zeiter S, Rammal H, Nasser M. Antioxidant, antiproliferative properties and chemical composition of the ethanolic extract from leaves and stems of Lebanese Anacyclus nigellifolius Boiss. J Adv Med Pharm Sci 2016;11:1-9.

16. Sujith K, Darwin CR, Suba V. Antioxidant activity of ethanolic root extract of Anacyclus pyrethrum. Int Res J Pharm 2011;2:222-6.

17. Sun J, Chu YF, Wu X, Liu RH. Antioxidant and ant proliferative activities of common fruits. J Agric Food Chem 2002;50:7449-54.

18. Cai Y, Luo Q, Sun M, Corke H. Antioxidant activity and phenolic compounds of 112 traditional Chinese medicinal plants associated with anticancer. Life Sci 2004;74:2157-84.
19. Dasilva LI, Karuppusamy A, Miyajima F, Violantei MP, Bieski IG, Balogun SO, et al. Antimicrobial and antioxidant activities of selected plants used by populations from Juruena valley, legal amazon. Int J Pharm Pharm Sci 2017;9:179-91

20. Farhan H, Rammal H, Hijazi A, Daher A, Reda M, Annan H, et al. Chemical composition and antioxidant activity of a Lebanese plant euphorbia macroclada schyzoceras. Asian Pac J Trop Biomed 2013;3:542-8

21. Farhan H, Rammal H, Hijazi A, Annan H, Daher A, Reda M, et al. Chemical composition, in vitro cytotoxicity and anti-free radical properties of six extracts from Lebanese Trigonella berythea boiss. Pak J Pharm Sci 2013;26:1157-63.

22. Farhan H, Rammal H, Hijazi A, Hamad H, Daher A, Reda M, et al. In vitro antioxidant activity of ethanolic and aqueous extracts from crude Malva parviflora L. grown in Lebanon. Asian J Pharm Clin Res 2012;5:234-8.

23. Bendjeddou D, Lalaoui K, Satta D. Immunostimulating activity of the hot water-soluble polysaccharide extracts of Anacyclus pyrethrum, Alpinia galanga and Citrullus colocynthis. J Ethnopharmacol 2003;88:155-60.

24. Krishnaraju AV, Rao TV, Sundararaju D, Vanisree M, Tsay HS, Subbaraju GV. International assessment of bioactivity of Indian medicinal plants using brine shrimp (Artemia salina) lethality assay. J Appl Sci Eng 2005;3:125-34. 